\title{
ANALISIS KETERKAITAN CORPORATE SOCIAL RESPONSIBILITY TERHADAP KINERJA KEUANGAN PERUSAHAAN TAMBANG DI BURSA EFEK INDONESIA TAHUN 2015-2019
}

\author{
Hendy Indra Sasmita \\ Program Studi Magister Manajemen Universitas Tarumanagara \\ hendy.indrasasmita@gmail.com
}

Masuk : 07-12-2020, revisi : 21-12-2020, diterima untuk diterbitkan : 22-12-2020

\begin{abstract}
Nowadays the issue of corporate social responsibility has become important, as well as challenging for many companies around the world. Aside from making a profit, many companies are obligated to conduct corporate social responsibility (CSR) to contribute to people's lives. The purpose of this research is to investigate whether the implementation of CSR activities has an association with the financial performance (FP) of Mining companies listed in the Indonesia Stock Exchange (IDX) in the period 2015-2019. Accounting-based measures and marketing-based measures are used to measure the financial performance of selected mining companies. With these two measured as well as variables such as CSR score, firm size, risk, industry sub-sector, R\&D intensity, Global Reporting Initiative indicator, assurance big four, research is conducted on a sample of 39 mining companies. Finally, SPSS (Statistical Package for Social Sciences) is used to test the developed hypothesis 2 regression model. The result suggests that some variables have an effect as well as no effect on ROA and EPS of mining companies in the period 2015-2019.

Keywords: Corporate Social Responsibility (CSR), Financial Performance (FP), Mining Companies' Disclosure, Return on Asset (ROA), Earning per Share (EPS), Reporting, Mining Companies
\end{abstract}

Abstrak: Pada zaman ini, isu tanggung jawab sosial perusahaan sudah menjadi isu yang
penting sekaligus menantang bagi perusahaan di seluruh dunia. Di samping mengejar
keuntungan, perusahaan dituntut untuk berkontribusi pada kehidupan masyarakat. Tujuan dari
penelitian ini adalah untuk menganalisa apakah implementasi CSR perusahaan tambang yang
terdaftar di BEI tahun 2015-2019 berdampak terhadap kinerja keuangannya. Metode
pengukuran "accounting-based" dan "marketing-Based" digunakan untuk melakukan analisa
kinerja keuangan perusahaan, bersama dengan variabel lain seperti skor CSR, ukuran
perusahaan, risiko, industri, biaya operasional, indikator GRI, audit "Big four", pada 39 sampel
perusahaan tambang yang dipilih. Sistem SPSS (Statistical Package for Social Sciences)
digunakan untuk menguji 2 regresi model hipotesis yang dikembangkan. Hasil penelitian
menyimpulkan ada beberapa variabel yang berdampak signifikan dan tidak signifikan terhadap
kinerja keuangan pada perusahaan tambang di BEI selama 2015-2019.

Kata Kunci: Tanggung Jawab Sosial Perusahaan, Kinerja Keuangan, Pengungkapan Perusahaan Tambang, Return on Asset, Laba per Saham, Perusahaan Tambang

\section{PENDAHULUAN}

Pada dasarnya, perusahaan menjalankan bisnisnya untuk memperoleh profit sebanyakbanyaknya demi menjaga kelanjutan bisnis dan keberadaan perusahaan. Namun tidak dapat dipungkiri kegiatan bisnis yang dijalankan mengakibatkan dampak negatif bagi masyarakat dan lingkungan sekitar. Salah satu industri yang sedikit banyak memberikan dampak negatif adalah perusahaan di industri tambang. Terlepas dari dampak positif perusahaan tambang, tidak dapat dipungkiri banyak dampak negatif dari beroperasinya perusahaan tambang seperti merusak lingkungan sekitar, mengancam keanekaragaman hayati, dan kesehatan manusia. 
Oleh karena itu seiring berjalannya waktu, perusahaan tambang diminta melakukan tanggung jawab sosial perusahaan, atau yang dikenal dengan istilah CSR. Pada penelitian ini, pokok permasalahan yang dibahas adalah bagaimana level pengungkapan CSR pada perusahaan sektor pertambangan yang terdaftar di Bursa Efek Indonesia (BEI) di periode 2015 sampai 2019, dan apakah implementasi CSR yang dilakukan berdampak signifikan atau tidak pada kinerja keuangan yakni "Return on Asset" (ROA) dan "Earning Per Share" (EPS), pada perusahaan tambang terkait.

Tujuan dari penelitian ini adalah untuk menjawab pokok permasalahan yang disebutkan sebelumnya yakni untuk mengetahui seberapa intens implementasi CSR perusahaan tambang, sekaligus mengetahui signifikan atau tidaknya implementasi CSR terhadap kinerja keuangan perusahaan tambang yang diukur dengan ROA dan EPS. Hasil dari penelitian diharapkan dapat memberikan informasi kepada investor dan masyarakat sebagai tolak ukur dalam melakukan investasi di perusahaan terkait dan sumber informasi perihal kontribusi CSR perusahaan terhadap lingkungan sekitar.

\section{LANDASAN TEORI}

Istilah “Corporate Social Responsibility" sudah menjadi popular di tahun 1960-an. Pada tahun 1963, Joseph W. McGuire menyatakan bahwa tanggung jawab perusahaan tidak hanya pada keuntungan perusahaan semata, namun juga perlu untuk memperhatikan kesejahteraan masyarakat, pendidikan, kebahagiaan karyawan, masalah sosial dan lingkungan (Carroll, 2008). Pada dasarnya, CSR adalah bentuk dari peran dan komitmen perusahaan untuk membangun relasi dan memberikan kontribusi yang positif bagi masyarakat, lingkungan, dan pemangku kepentingan seperti konsumen, supplier, pemerintah, dan investor (Sharma \& Kiran, 2013).

Konsep CSR seperti dikutip oleh Budiarti dan Raharjo (2014) merujuk pada tanggung jawab perusahaan untuk memberikan kontribusi positif yang dapat membantu masyarakat dalam berbagai aspek seperti ekonomi, pendidikan, pangan, dan lain-lain sekaligus berperan dalam upaya melestarikan lingkungan. Dalam pengungkapan implementasi CSR yang dilaporkan dalam bentuk laporan CSR dan/atau laporan tahunan, tentu perusahaan menggunakan standar tertentu dalam membuat laporan yang diperlukan. Standar yang dipakai dalam membuat laporan ini adalah standar yang dikenal dengan istilah "Global Reporting Initiative", yang biasa disingkat GRI.

Seperti dikutip dari website Global Reporting Initiative (2020), lembaga GRI adalah organisasi internasional yang didirikan pada tahun 1997. Tujuan dari lembaga ini adalah untuk membantu entitas dalam memahami dan mengungkapkan dampak sosial dan lingkungan seperti perubahan iklim, hak asasi manusia, kesejahteraan masyarakat, dan lain-lain yang diakibatkan oleh kegiatan operasional. Dengan begitu, baik perusahaan, lembaga-lembaga, maupun pemerintah dapat membuat keputusan terkait tindakan yang akan dilakukan untuk menjalankan bisnis yang ramah lingkungan dan membantu mensejahterakan masyarakat disekitarnya.

Dalam penelitian ini, analisis difokuskan pada keterkaitan dan pengaruh level pengungkapan implementasi CSR perusahaan tambang yang terdaftar di BEI tahun 2015-2019 terhadap kinerja keuangan perusahaan tambang berdasarkan "accounting performance" yang diukur dari aspek "Return on Asset (ROA)" dan "marketing performance" yang diukur dari aspek "Earning per Share (EPS)". Berikut adalah hipotesis yang dikembangkan dari penelitian ini:

Hipotesis 1: Ada atau tidak ada keterkaitan pengungkapan CSR terhadap kinerja keuangan perusahaan tambang yang diukur dari "accounting performance".

Hipotesis 2: Ada atau tidak ada pengungkapan CSR terhadap kinerja keuangan perusahaan tambang yang diukur dari "marketing performance". 
Penelitian ini terinsipirasi dari penelitan sebelumnya yang pernah dilakukan Moenna (2014) pada penelitian yang berjudul "Corporate Social Responsibility and Financial Performance: An Empirical Analysis on EU's top fifty Listed Companies Business". Penelitian ini melakukan analisis keterkaitan CSR dengan kinerja keuangan pada 50 perusahaan terbesar di Eropa selama kurun waktu 2009-2013, yang kinerja keuangannya diukur dengan variabel ROA dan EPS. Selain itu, penelitian ini juga terinspirasi dari penelitian sebelumnya yang dilakukan oleh Hagberg et al. (2015) pada penelitian yang berjudul "The Relationship between CSR and Financial Performance: A Quantitative Study Examining Swedish Publicly Traded Companies". Secara garis besar, penelitian ini melakukan analisis keterkaitan CSR dengan kinerja keuangan pada perusahaan-perusahaan besar di Swedia, yang kinerja keuangannya diukur dengan variabel ROA dan Tobin-Q.

\section{METODOLOGI PENELITIAN}

Jenis penelitian yang digunakan adalah penelitian kuantitatif. Menurut Aulia (2016), metode penelitian kuantitatif adalah metode untuk melakukan analisa melalui prinsip prinsip statistik. Pada penelitian ini, analisis dilakukan dengan memberikan "scoring" terhadap pengungkapan implementasi CSR perusahaan tambang yang terdaftar di Bursa Efek Indonesia (BEI) pada periode 2015 sampai 2019. Setelah memberikan scoring, peneliti melakukan pengujian ada dan/atau tidaknya keterkaitan dan pengaruh scoring pengungkapan CSR terhadap kinerja keuangan perusahaan yakni pada "Return on Asset (ROA)" dan "Earning per Share" (EPS).

Sumber data diperoleh dari laporan tahunan dan/atau laporan berkelanjutan perusahaan tambang yang terdaftar di Bursa Efek Indonesia (BEI) tahun 2015-2019. Total terdapat 39 perusahaan tambang yang terdiri dari subsektor logam dan mineral, tanah dan batu galian, batu bara, minyak mentah dan gas bumi yang menjadi sampel penelitian ini.

Perihal variabel, ada tiga variabel yang dibahas dalam penelitian ini yakni variabel dependen, variabel independen, dan variabel kontrol. Yang menjadi variabel dependen pada penelitian ini adalah "Return on Asset" (ROA) dan "Earning per Share" (EPS). Lalu yang menjadi variabel independen adalah scoring level pengungkapan CSR perusahaan tambang, dan yang menjadi variabel kontrol adalah ukuran perusahaan, risiko, industri, biaya operasional perusahaan, standar GRI, dan "assurance big four". Secara garis besar berikut adalah model penelitian yang dipakai dalam penelitian ini:

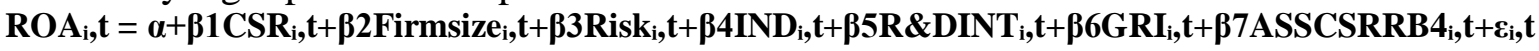

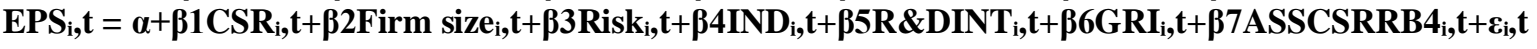

Dimana model penelitian ini menekankan pada pengaruh variabel-variabel seperti ukuran perusahaan, score CSR, risiko, biaya operasional, indikator GRI dan indikator big four KAP terhadap kinerja keuangan perusahaan dalam aspek ROA dan EPS (Ahmed \& Uchida, 2009). Secara garis besar metode analisis yang dipakai dalam penelitian ini ada tiga. Yang pertama adalah statistik deskriptif. Menurut Bråtenius dan Melin (2015), statistik deskriptif adalah analisa yang memberi penjelasan dan karakteristik data dengan nilai rata-rata (mean), standar deviasi, nilai maksimum, dan nilai minimum.

Yang kedua adalah uji asumsi klasik yang terdiri dari empat pengujian. Pengujian pertama adalah uji normalitas yang terdiri dari dua cara yakni konsep uji Kolmogorov Smirnov yang menekankan pada perbandingan distribusi data (variabel data dependen yang diuji normalitasnya) dengan distribusi normal baku, dan grafik normal probability yang menggunakan grafik normal probability plot untuk mengetahui apakah hasil data yang diperoleh, yang dalam hal ini adalah variabel data "Return on Asset" (ROA) dan "Earning per Share" (EPS) mempunyai distribusi data yang normal atau sebaliknya. Yang kedua adalah uji multikolinearitas untuk menguji adanya multikolinearitas antara variabel independen dan model regresi. Pengujian ketiga adalah uji autokorelasi untuk menentukan apakah ada korelasi variabel dalam model regresi dengan perubahan waktu. Pengujian keempat adalah uji 
heteroskedastisitas digunakan untuk menguji adanya ketidaksamaan varian dari semua pengamatan pada persamaan regresi (Adhitya et al., 2016).

Metode analisa ketiga adalah uji hipotesis yang terdiri dari tiga pengujian. Seperti yang dikutip oleh Yaparto et al. (2013), pengujian pertama adalah uji koefisien determinasi $\left(\mathrm{R}^{2}\right)$ digunakan untuk mengetahui seberapa besar kemampuan suatu model dalam memprediksi dan menjelaskan variabel-variabel dependen. Yang kedua adalah uji simultan (Uji F) dilakukan untuk mengetahui apakah variabel independen mempengaruhi variabel dependen secara simultan atau bersama-sama. Yang ketiga adalah uji parsial dilakukan untuk menguji pengaruh variabel independen secara parsial atau terpisah terhadap variabel dependen.

\section{ANALISA DAN PEMBAHASAN}

Dari hasil pengujian statistik deskriptif pada variabel dependen ROA, dapat dilihat bahwa perusahaan tambang yang terdaftar di Bursa Efek Indonesia (BEI) pada periode 2015 sampai 2019 secara umum memiliki kemampuan untuk memperoleh keuntungan sebesar 55\% dari total aset yang mereka miliki. Nilai maksimum mencerminkan efektivitas perusahaan tersebut dalam mengelola asetnya. Untuk pengujian pada variabel dependen EPS, dapat dilihat bahwa perusahaan tambang yang terdaftar di Bursa Efek Indonesia (BEI) periode 2015-2019 secara umum mencerminkan nilai rata-rata 193,71.

Dari hasil uji asumsi klasik, metode pengujian yang digunakan adalah uji normalitas yang memiliki dua cara analisa yakni uji Kolmogorov-Smirnov, yang menyimpulkan bahwa model regresi yang dianalisis memiliki distribusi yang normal, dan uji grafik P plot dimana dari grafik menunjukkan bahwa titik-titik menyebar pada garis diagonal dan mengikuti arah diagonal garis tersebut, dengan demikian dapat disimpulkan bahwa data terdistribusi secara normal.

Pengujian kedua adalah uji multikolinearitas dimana berdasarkan hasil uji multikolinearitas dapat dilihat bahwa nilai VIF setiap variabel lebih kecil $(<)$ dari 10 dan nilai tolerancenya lebih besar ( $>$ ) dari 0,1 atau 10\%. Dengan demikian bisa disimpulkan bahwa tidak ada korelasi antara variabel independen atau tidak ditemukan terjadinya multikolinearitas.

Pengujian ketiga adalah uji autokorelasi yang berdasarkan hasil uji Durbin Watson menyimpulkan bahwa tidak terjadi autokorelasi pada model regresi pada variabel dependen EPS dan ROA, sehingga bisa dikatakan telah memenuhi uji asumsi klasik.

Pengujian keempat adalah memakai uji heteroskedastisitas, yang mengindikasikan bahwa seluruh variabel memiliki nilai signifikansi lebih dari (>) 0,05 sehingga tidak ada heteroskedastisitas dan pengujian yang dilakukan telah memenuhi kaidah uji asumsi klasik.

Dari hasil uji hipotesis ada tiga pengujian yang dilakukan. Yang pertama adalah uji koefisien determinasi. Pengujian ini menyimpulkan bahwa variabel-variabel independent yaitu Nilai Level Pengungkapan CSR, Ukuran Perusahaan, Tingkat Risiko Perusahaan, Industri Perusahaan, Intensitas "Research \& Development", Level Pengungkapan CSR berbasis Standar GRI, dan Assurance Big four dapat menjelaskan variabel dependen Earning Per Share sebesar 21,2\%. Perihal variabel dependen ROA, disimpulkan bahwa Nilai Level Pengungkapan CSR, Ukuran Perusahaan, Tingkat Risiko Perusahaan, Industri Perusahaan, Intensitas "Research \& Development", Level Pengungkapan CSR berbasis Standar GRI, dan Assurance Big four dapat menjelaskan variabel dependen Return on Asset sebesar 26,8\%.

Pengujian kedua adalah uji simultan (Uji F). Dengan variabel dependen EPS yang menghasilkan uji F menunjukkan nilai signifikansi F lebih kecil $(<)$ dari 0,05. Dengan demikian dapat diambil kesimpulan bahwa variabel-variabel independen yaitu Nilai Level Pengungkapan CSR, Ukuran Perusahaan, Tingkat Risiko Perusahaan, Industri Perusahaan, Intensitas "Research \& Development", Level Pengungkapan CSR berbasis Standar GRI, dan Assurance Big four mempengaruhi variabel dependen EPS secara bersama-sama. Untuk pengujian dengan variabel dependen ROA, hasil uji F menunjukkan nilai signifikansi $\mathrm{F}$ lebih kecil $(<)$ dari 0,05. Dengan demikian dapat diambil kesimpulan bahwa variabel-variabel 
independen yaitu Nilai Level Pengungkapan CSR, Ukuran Perusahaan, Tingkat Risiko Perusahaan, Industri Perusahaan, Intensitas "Research \& Development", Level Pengungkapan CSR berbasis Standar GRI, dan Assurance Big four mempengaruhi variabel dependen ROA secara bersama sama.

Pengujian ketiga adalah dengan memakai uji parsial yang secara garis besar pada variabel dependen EPS, variabel seperti Skor CSR, Risiko, Industri, memiliki korelasi positif dengan EPS. Namun variabel seperti Ukuran Perusahaan, "Research \& Development", GRI, dan "Assurance Big four" tidak memiliki korelasi dengan EPS. Terkait ROA, variabel seperti Skor CSR, Risiko, Industri, "Research \& Development", memiliki korelasi positif dengan ROA. Namun variabel seperti Ukuran Perusahaan, GRI, "Assurance Big Four" tidak memiliki korelasi dengan ROA.

\section{PENUTUP}

\section{Kesimpulan}

Dari hasil penelitian, dapat disimpulkan bahwa perusahaan tambang yang dijadikan sampel sudah melakukan CSR, namun seberapa intens CSR yang dilakukan berbeda beda dari tiap perusahaan. Hasil penelitian juga menunjukkan bahwa ada variabel variabel memiliki korelasi signifikan namun ada juga yang tidak signifikan terhadap kinerja ROA dan EPS.

\section{Implikasi}

Peneliti selanjutnya dapat melakukan penelitian serupa dengan variabel dan sampel yang berbeda dengan tujuan untuk menganalisa apakah implementasi CSR semakin intensif atau sebaliknnya, serta menguji pengaruh bervariasi antara variabel yang satu dengan yang lain.

\section{Keterbatasan}

Dari hasil penelitian, ada beberapa keterbatasan. Diantaranya adalah populasi yang digunakan terbatas pada 39 perusahaan dan 195 observasi saja. Penggunaan populasi dan sampel yang lebih besar dapat meningkatkan keakuratan penelitian.

\section{DAFTAR PUSTAKA}

Adhitya, R., Suhadak, \& Nuzula, N. F. (2016). Pengaruh pengungkapan CSR dan profitabilitas terhadap nilai perusahaan (Studi pada perusahaan sektor pertambangan yang terdaftar di Bursa Efek Indonesia pada tahun 2011-2013). Jurnal Administrasi Bisnis (JAB), 31(1), 66-72.

http://administrasibisnis.studentjournal.ub.ac.id/index.php/jab/article/viewFile/1214/139 6

Ahmed, S., \& Uchida, S. (2009). Corporate social responsibility and financial performance linkage: A preliminary study for the conceptual framework. Nagasaki University's Academic Outpit SITE, 50, 43-51. https://nagasaki-

u.repo.nii.ac.jp/?action=pages_view_main\&active_action=repository_view_main_item_ detail\&item_id=17757\&item_no=1\&page_id=13\&block_id=21

Aulia, R. (2016). Metode penelitian kuantitatif. Globalstatistik Academic. https://www.globalstatistik.com/metode-penelitian-kuantitatif/

Bråtenius, A. L. H., \& Melin, E. J. (2015). The impact of CSR on financial performance: An event study of abnormal stock returns of Swedish companies as a reaction to the release of the Folksam Index of Corporate Social Responsibility [Copenhagen Business School]. https://researchapi.cbs.dk/ws/portalfiles/portal/58411722/anna_linnea_helena_braatenius_og_emilie_jo sefin_melin.pdf

Budiarti, M., \& Raharjo, S. T. (2014). Corporate Social Responsibility (CSR) dari sudut pandang perusahaan. Share : Social Work Journal, 4(1), 13-29. https://doi.org/10.24198/share.v4i1.13045 
Carroll, A. B. (2008). A history of corporate social responsibility: Concepts and practices. In The Oxford Handbook of Corporate Social Responsibility (pp. 19-46). Oxford University Press. https://doi.org/10.1093/oxfordhb/9780199211593.003.0002

Global Reporting Initiative (GRI). (2020). GRI - Mission \& history. Global Reporting Initiative. https://www.globalreporting.org/about-gri/mission-history/

Hagberg, C., Johansson, S., \& Karlsson, A. (2015). The relationship between CSR and financial performance: A quantitative study examining Swedish publicly traded companies [Linnaeus University]. https://www.divaportal.org/smash/get/diva2:839031/FULLTEXT01.pdf

Moenna, R. (2014). Corporate social responsibility and financial performance: An empirical analysis on EU's top fifty listed companies [Erasmus Universiteit Rotterdam]. https://thesis.eur.nl/pub/17318/MA682-Moenna_372659.pdf

Sharma, A., \& Kiran, R. (2013). Corporate social responsibility: Driving forces and challenges. International Journal of Business Research and Development, 2(1), 18-27. https://doi.org/10.24102/ijbrd.v2i1.182

Yaparto, M., Frisko, D., \& Eriandani, R. (2013). Pengaruh corporate social responsibility terhadap kinerja keuangan pada sektor manufaktur yang terdaftar di Bursa Efek Indonesia pada periode 2010-2011. Calyptra : Jurnal Ilmiah Mahasiswa Universitas Surabaya, 2(1), 1-19. https://journal.ubaya.ac.id/index.php/jimus/article/view/106/84 